\title{
Digital Service Taxes and Their Application
}

\author{
Kelbesa Megersa \\ Institute of Development Studies
}

15 December 2020

\section{Question}

- What is the evidence on Digital Service Taxes (DSTs) and their application proposed, announced and implemented?

- $\quad$ An overview of and the categories of DST taxes and evidence on the economic impact and efficiency of the different types of DSTs?

\section{Contents}

1. Overview

2. The Main (OECD) Proposed Approaches to Tax the Digital Economy

3. Brief Assessment of The Economic Impact Of DST

4. Mapping The Implementation Of Digital Service Taxes In Developing Countries

5. Good DST Design

6. References

7. Annex: OECD's Two-Pillar DST Approach

The K4D helpdesk service provides brief summaries of current research, evidence, and lessons learned. Helpdesk reports are not rigorous or systematic reviews; they are intended to provide an introduction to the most important evidence related to a research question. They draw on a rapid deskbased review of published literature and consultation with subject specialists. 


\section{Overview}

For many developing economies that have seen a rise in e-commerce activity within their borders, and a decline in income from traditional industries as a result of COVID-19, the digital economy offers a potentially unexploited source of tax revenue. In this regard, the Organisation for Economic Co-operation and Development (OECD) has ongoing work on potential approaches to taxing digital services (see Section 2.2 and Annex). OECD's work will provide much-needed clarification on the introduction of a digital tax. As a result, more developing countries may soon begin adopting some sort of digital tax.

The nature and scope of economic activities which may be considered subject to the Digital Services Tax (DST) may vary from country to country, and may even include companies which do not particularly find themselves to be engaged in digital services or e-commerce activities. It will, therefore, be necessary for businesses operating in multiple jurisdictions across developing countries to keep up with the changes in digital taxes and in particular, to pay close attention to whether their activities will lead to tax liability (Mekgoe and Hassam, 2020).

Before implementing a DST scheme, developing countries are advised to perform an indepth cost-benefit analysis and due considerations, such as the impact of consumption-based taxation (e.g. a value-added tax(VAT)) on remote sales (Bunn et al., 2020). ${ }^{1}$

Some developing (and several developed) countries have already unilaterally implemented a "provisional" DST system. That is, before the conclusion of the ongoing OECD's multilateral negotiations on DSTs that involves over 130 countries (Asen, 2020). ${ }^{2}$ Other developing countries are on the process of implementing DST or have simply announced that they will implement a DST soon. Although most of the countries so far actively working on DST (i.e. be it at an implementation or simply announcement phase) are rich countries, a growing list of developing countries (mainly middle income) are joining the process. Some examples include the following:

- Malaysia introduced a DST on digital services (i.e. a service tax of $6 \%$ on services that are delivered or subscribed over the internet or electronic networks) since the beginning of 2020. Malaysia charges the service tax on foreign suppliers of digital services to Malaysia-based customers. Information on the impact of the DST is limited due to the recent introduction of the tax. However, it is estimated that the country aims to collect about RM300 million (over USD 70 million) in 2020. Some estimates on the full revenue potential of the DST have put the figure around RM2.4 billion (over USD 590 million) in digital tax revenue.

\footnotetext{
${ }^{1}$ Some of the implications (e.g. costs and challenges) linked to DST have been provided in Section 3 of the report. In addition, some attributes of a good DST system (i.e. which minimize adverse implications) have been provided in section 5 .

${ }^{2}$ Approximately half of all European OECD countries have either announced, proposed or implemented a DST on large digital companies' selected gross revenue streams. Similarly, UK's Finance Bill 2020, which includes a DST legislation, has received an ascent and DST is retroactively effective as of 1 April 2020. However the United States has responded with retaliatory threats to the introduction of DST in European countries because it believes that these taxes primarily affect U.S. businesses and are thus perceived as discriminatory (Asen, 2020). These development exemplify some of the challenges facing the worldwide adoption of DSTs.
} 
- Indonesia introduced a DST system (i.e. VAT at a rate of $10 \%$ on digital services supplied by non-residents) since August 2020. The effectiveness of the DST has yet to be determined given its recency. However, it was reported that the new DST VAT rules resulted in USD 20.9 million being collected in the first three months of the DST's implementation.

- Kenya has proposed a DST (i.e. a service tax of $1.5 \%$ on the gross transactional value of digital services) which will be effective as from January 2021. Although there are projections that the DST will generate more tax revenue for the government, there are also indications that it will entail some challenges and costs. Particularly, there are worries about i) consumers paying more for digital services, ii) businesses in the digital sector might disproportionately absorb the cost, iii) compliance or tax enforcement challenges, and iv) challenges on imposing penal measures for non-residents.

- Nigeria has proposed a DST, but it has not yet implemented it nor given any clear timeline for implementation. There are indications that it will be a $30 \%$ service charge that is included in gross income for corporate income tax (CIT). There are also hints that the DST will entail compliance and enforcement challenges, among other issues.

- Argentina had introduced a DST system (i.e. a VAT on digital services) in June 2018. The rate was expanded up to 30 percent in 2020. Argentina's approach to the DST is different from OECD's guidelines - since the liability is on the local payment provider instead of a non-resident digital services supplier.

- Chile introduced a DST (as a $19 \%$ VAT on the provision of digital services) applicable to services such as Amazon, Netflix, AirBnB, and Spotify since June 2020. Some forecasts show that the country expects to gather around USD 2.2 billion as tax revenue from the DST. However, the DST has already led to a considerable rise in prices of digital services faced by Chilean consumers.

However, it is also important to mention that the literature on DST (particularly academic research) is very limited - although growing. The evidence base around the economic impacts (on consumers, businesses, and government revenue) is particularly scarce. This is partly due to the quite recent nature of DST implementation. The evidence is even scarcer for developing countries - especially low-income countries where the use of digital services is still comparatively low. Due to these limitations, this rapid evidence review looks at different types of available literature - including reports and blogs issued by international financial institutions and development agencies.

The rest of the report is structured as follows. Section 2 looks at key proposed approaches to tax the digital economy, i.e. OECD's multilateral DST proposal. Among other issues, this discusses the different "pillars" of the OECD proposal - whose details are given in the Annex section of this report. The Annex also features the digital services that will be affected by DST such as automated digital services, professional services, and consumer-facing digital businesses. Section 3 provides a very brief account of the economic impact of DST. Specifically, the gains in tax revenue to governments, the implications to tax compliance costs, and other challenges (such as the impact on investment, innovation, and economic growth; issues of over-taxation; implications to the welfare and economic incidence of taxation on consumers and businesses). Section 4 provides a brief mapping of the implementation of digital service taxes in developing countries. It particularly gathers the experience of DSTs in developing countries (mainly middleincome economies) in Asia, Africa, and Latin America. Although there is a growing discussion and plan about the adoption of DST, few countries have so far explicitly announced the 
introduction of DST and fewer have moved on to introduce it. While assessing country experiences on DST, Section 4 provides a brief description of each DST system, type/categories of taxes involved, and about the economic impact of the DST. Section 5 provides a brief account or attributes of a "good" DST system.

\section{The Main (OECD) Proposed Approaches to Tax the Digital Economy}

\subsection{Current state of affairs: COVID-19 and Digital Services Tax (DST)}

As the COVID-19 pandemic is disrupting economies around the world, businesses are finding it difficult to contain losses and avoid cutting jobs in traditional industries such as mining and manufacturing. Normally, the economic slowdown transforms into declining tax revenue for tax authorities around the world, which is likely to lead the tax authorities to look at other sources of tax collection such as DST. This revenue problem will be magnified in developing countries (particularly low-income ones) since most of them have commodity-based economies that rely on high commodity prices - which tend to slump due to low demand in times of crisis (Mekgoe and Hassam, 2020).

Conversely, it appears that the e-commerce or digital services sector has largely escaped unharmed from COVID-19's adverse economic shocks. Not only has the sector survived through the restrictive measures put in place by different governments to contain the spread of COVID-19, but it appears to be even thriving in the current adverse circumstances. In general, companies operating in the digital economy, including new entrants to the market, have reported a surge in earnings and in some cases, have had to hire additional staff to meet an unparalleled increase in demand for their goods and services. Because of this, the digital economy is expected to gain the focus of many revenue authorities in developing countries - i.e. as an unexploited source of tax revenue (Mekgoe and Hassam, 2020).

\subsection{The OECD proposed approaches to DST}

Concerns have been raised over the last few years that the current international tax system does not properly capture the digitalisation of many services and economies. Multinational businesses generally pay corporate income tax under current international tax rules where production occurs rather than where their consumers are located. Some, however, still argue that companies that derive income from users abroad through the digital economy (i.e. without a physical presence) should not be subject to corporate income tax in the foreign country where the users of their digital services are located (Asen, 2020).

The OECD has been organising negotiations with over 130 countries to update the international tax system to address these concerns. The current proposal would require multinational businesses (e.g. based in advanced economies like the US) to pay some of their income taxes where their consumers or users are located (e.g. in developing 
economies). According to the OECD, a multilateral agreement on DST could possibly be realised in 2021 (Asen, 2020).

In a recent report, OECD (2020) issued its report on "Action 1" of the Base Erosion and Profit Shifting (BEPS) project which tackles the taxation of digital services. ${ }^{3}$ In this report, the OECD concluded that the digital economy does not engender exceptional BEPS issues even though some of its important elements may heighten BEPS risks. In order to address any potential BEPS risks from digital transactions, the report recommended that the rules on permanent establishments, transfer pricing and controlled foreign companies should be reinforced. Following the publication of the "Action 1" report, the OECD attempted to find consensus-based answers to the problems of the digital economy. In this respect, a "twopillar" approach was developed by the OECD (Mekgoe and Hassam, 2020; OECD, 2020a):

An outline of a unified DST approach/architecture has been endorsed by the "OECD Inclusive Framework". This is meant to serve as the basis for negotiation on DST and a consensus-based solution (see Annex). OECD's unified approach is intended to adapt the existing taxation rights of countries - so as to consider new business models and reallocate taxation rights for the benefit of user countries of digital services (Deloitte, 2020; OECD, 2020a).

The OECD recognises that political differences and technical challenges do remain. Nevertheless, countries participating in the OECD/G20 Inclusive Framework have reaffirmed their commitment to achieving a multilateral solution by the end of 2020 (Deloitte, 2020; OECD, 2020a).

The OECD proposals encompass some complex areas that require further work. Some of these complications appear where i) the sale to the market of tangible goods may or may not give rise to an active non-physical (digital) presence and ii) the tax threshold may vary depending on the size of the market. In addition, according to the degree of digitalisation of the enterprise, the amount of residual profit to be apportioned to market countries may be weighted. These concepts are likely to be difficult to implement in practice and may contradict the desire for simplicity (Deloitte, 2020).

Deloitte (2020) noted, however, that businesses would be happy to see that i) double taxation get eliminated; ii) compulsory mechanisms for dispute resolution become more prominent; and iii) compliance processes getting simplified, including a central filing option (such as a one-stopshop). Crucially, any new taxing right will be 'ring-fenced' so as not to have consequences for other taxes that are already in place - such as VAT or customs duties (Deloitte, 2020).

Note: Details of the OECD DST proposal are given in the Annex section, at the end of the report.

\footnotetext{
${ }^{3}$ http://www.oecd.org/tax/beps/statement-by-the-oecd-g20-inclusive-framework-on-beps-january-2020.pdf
} 


\section{Brief Assessment of The Economic Impact Of DST}

There is a limited evidence base on the economic impact of DST from developing countries because most of them have not yet implemented DST. Further, the few middle-income countries that have DST in place have done so only recently (see Section 4). Some of the key economic impacts witnessed from the DSTs that have been implemented (e.g. new VAT on international digital services) in some high- and middle-income countries/regions include the following:

\section{Gains in Tax Revenue:}

- The European Union's VAT revenues collected from VAT on cross-border digital sales climbed from $€ 3$ billion (USD 3.4 billion) in 2015 to over $€ 4.5$ billion (USD 5 billion) in 2018 (Bunn et al., 2020; OECD, 2020b).

- Similarly, Australia reported AUD 348 million (USD 242 million) of new DST revenues in 2017 - which was gathered from the adoption of OECD standards on online sales of digital services and digital products (Bunn et al., 2020; OECD, 2020b).

\section{Implications to Tax Compliance Costs:}

- The existence of DST could make foreign companies face big problems in complying with different and evolving requirements in each of the countries where they have digital sales. It can be extremely costly, and possibly prohibitive, to meet the reporting requirements. Even if only the software requirements and the continuous updates required were to be taken into account, the operating costs rise substantially with each country in which they have sales (Bunn et al., 2020; Bulusu and Ali, 2020). ${ }^{4}$

- Due to e-invoicing regulations, retailers could face considerable obstacles. This is due to the large number of transactions they handle every day. The regulations require businesses to send sales invoice data directly to the tax authorities, often in realtime (i.e. on or near the time) of the transaction (Bulusu and Ali, 2020).

- An interim DST tax measure (as several countries are already doing, i.e. before the resolution on the multilateral OECD DST scheme) may also result in substantial enforcement and administrative costs that may be disproportionate to the amount of tax generated under the DST, especially if the measure is intended to be temporary. The taxing jurisdiction may also encounter obstacles in auditing and checking the authenticity of the returns submitted and payments made by non-residents (OECD, 2018; Kofler and Sinnig, 2019).

- Moreover, taxes (DST or otherwise), once implemented, are always difficult to abolish. Thus, considering the time that might be required to create and enforce an interim DST measure, it might become questionable to implement a whole new set of rules (with all the relevant administrative processes that are necessary) that may apply only for a limited period of time (OECD, 2018; Kofler and Sinnig, 2019).

\footnotetext{
${ }^{4}$ More than 80 countries have already implemented requirements for companies to use e-invoicing for reporting taxes on business transactions (Bunn et al., 2020).
} 


\section{Other challenges:}

It is difficult to impose local rules on companies that are based abroad, particularly if there is no cooperation agreement between the countries concerned. The supplier of the digital services does not file in the country of destination if its sales surpass the threshold to escape additional enforcement obligations, and the country of origin of the supplier has no motivation to ensure that the sales regime is enforced correctly. Conversely, many tax authorities do not have the ability to deal with the number of transactions to be checked (Bunn et al., 2020).

OECD (2018) also noted that the "tax challenge" posed by "digitalisation" relates to the manner in which certain businesses can now engage extensively in the economic life of a tax jurisdiction with little or no taxable presence. Some of the main risks and threats relate to the adverse economic effects of "equalisation taxes" (OECD, 2018; Kofler and Sinnig, 2019).

- Effect on investment, innovation, and growth: Any tax on the provision of particular services is likely to raise the cost of capital and reduce the incentive to invest with a detrimental impact on growth. Furthermore, a gross tax only applicable to digitised industries would risk decreasing investment in innovation for those companies that are subject to or indirectly affected by the tax and thus could effectively penalise start-ups and other rising firms with losses or reduced profitability (OECD, 2018; Kofler and Sinnig, 2019).

- Possibility for over-taxation: In order to comply with its international commitments, a country may be expected to apply DST tax to both citizens and non-residents, and to restrict any credit system against other taxes that may raise the issue of over-taxation, e.g. where payments are subject to both corporate and equalisation taxes (OECD, 2018; Kofler and Sinnig, 2019).

- Effect on welfare: A DST, depending on how it is implemented, could be similar to an input tax, which means that it is likely to distort the choices made by companies on inputs. Thus, it could distort the production (of digital service) and likely lead to a negative effect on the overall welfare of the economy and on its productivity (OECD, 2018; Kofler and Sinnig, 2019).

- Possible economic incidence of taxation on businesses and consumers:

Depending on the price sensitivities of the seller and the buyer of digital services and the market structure, the incidence of taxes could be entirely or partially passed on to local customers in the form of higher prices for digital services (OECD, 2018; Kofler and Sinnig, 2019).

Therefore, the DST/VAT treatment of some digital services could considerably raise prices for certain services - depending on the level of tax (Bunn et al., 2020). For instance:

- Chileans have started paying significantly more for video streaming services starting in June 2020, when the government's 19 percent VAT began to apply to such digital services (Azzopardi, 2020; Taxlinked, 2020). See also Section 4.2.2.

- Mexican streaming customers also faced 16 percent VAT on streaming services since June 2020 (Bunn et al., 2020; Taxlinked, 2020; Mialik, 2020). See also Section 4.2.2 
Finally (and importantly), VAT collected from cross-border digital transactions still represent less than 0.5 percent of total VAT revenue in many countries.

- For instance, the European Union's total VAT revenue was $€ 1,135$ billion (USD1,271 billion) in 2018 (Eurostat, 2020). Consequently, VAT revenue raised from these measures only represented well below 0.5 percent of the total VAT raised in the EU considering the $€ 4.5$ billion (USD 5 billion) in VAT revenues from cross-border digital sales in the same year (Bunn et al., 2020b).

- Similarly, Australia's Goods and Services Tax (GST) revenue from online digital sales represented 0.5 percent of the total VAT collection (Bunn et al., 2020; OECD, 2020c).

- Nonetheless, as e-commerce continues to expand, so will VAT revenues from cross-border digital transactions. This will expand the VAT base and could enable governments to lower the DST tax rates - while still enabling them to raise an equivalent amount of revenue in the long term (Bunn et al., 2020).

\section{Mapping The Implementation Of Digital Service Taxes In Developing Countries}

Although a growing number of developing countries are extending the scope of their indirect taxes (e.g. VAT) to digital services, most have not introduced direct tax

provisions. In view of the inevitable emphasis of developing country tax authorities on the digital economy (which, in part, is accelerated by COVID-19), it is now necessary to reflect on developments in digital services taxes across developing countries - with a specific focus on direct taxes. That is, some form of direct digital services tax that applies to non-residents with no physical presence in their respective countries (Mekgoe and Hassam, 2020).

A major reason cited by some developing-country governments for failing to introduce unilateral tax solutions is that they are waiting for the finalisation of work on the digital economy. The OECD initially intended to finalise the work on the first and second "pillars" (see Annex section) by the end of 2020. It is unlikely that this deadline can still be met, considering the COVID-19 limitations in effect around the world (Mekgoe and Hassam, 2020). A more (likely) deadline is now somewhere in 2021 (Asen, 2020).

Extended delays in the completion of OECD's multilateral DST proposal may encourage more developing countries to introduce unilateral DST instruments to tax the digital economy - as various governments may fear a loss of potential revenue. This would be particularly true given the rise in profits generated by digital service-oriented companies during the COVID-19 pandemic (Mekgoe and Hassam, 2020). ${ }^{5}$

\footnotetext{
5 The African Tax Administration Forum (ATAF) has recently also started developing a "suggested approach to drafting Digital Services Tax" that will be used member countries as a toolkit for developing digital services tax laws. This is an indication that this topic is now a priority for most tax authorities in Africa (Mekgoe and Hassam, 2020).
} 
Some of the notable digital services tax laws from developing countries in Asia and Africa that have been proposed, announced/being-implemented or already implemented are summarised below:

\subsection{Countries Where DST is Being Implemented (or Proposed and On-process)}

\subsubsection{Asia}

\section{Malaysia:}

\section{DST Implementation}

- Effective date: 1 January 2020

- Rate: $6 \%$

- Threshold: If the value of the services provided reaches the threshold of RM 500,000 (approximately USD 120,000) for a period of 12 months, the foreign supplier is required to register to collect and remit 6 percent of Malaysia's service tax on sales to Malaysian customers. The presence of a threshold means that sales to customers based in Malaysia would have to be recognised and controlled (Taxamo, 2020a).

\section{Description of the DST and Tax Categories}

Malaysia announced the implementation of a tax on imported digital services in its budget for 2019. International service providers will be required to register and remit relevant service taxes to Malaysian customs for imported online services by users effective 1 January 2020. These imported digital services must be subject to a tax rate of $6 \%$ on sales to customers in Malaysia (Taxamo, 2020b).

Malaysia's DST describes "digital services" as any service that is provided or subscribed over the Internet or any other electronic network and that cannot be obtained without the use of information technology (e.g. web platform) and where the delivery of the service is essentially automated (Taxamo, 2020a).

Malaysia is the second Southeast Asian country, after Singapore, to expand its tax rules to cover digital supplies by foreign suppliers. Both tax jurisdictions are now in the process of adopting new regulations at the same time. This extension of Malaysia's service tax is identical to the Singapore Goods and Services Tax (GST) which was extended on 1 January 2020. In Malaysia, the broad purpose of this (digital) service tax extension is to level the playing field for local digital services providers to compete equally with foreign firms (Taxamo, 2020a).

\section{Economic Impact of the DST (Intended/Realised)}

Malaysia expects to actually raise RM300 million in 2020 from the 6 percent digital service tax imposed by international providers, which came into effect on 1 January this year. As for the full 
revenue potential of the DST, some preliminary estimates indicate that the $6 \%$ tax rate on the DST could theoretically produce about RM2.4 billion in digital tax revenue based on the Malaysian Department of Statistics survey of Malaysia's RM398 billion in e-commerce revenue in 2015 (Malaysian Reserve, 2020).

There were a total of 248 foreign digital service providers registered for tax purposes, as of end July 2020. Some major digital service providers included Netflix Inc, Spotify AB, Google LLC and Airbnb Inc. There have been arrangements on special treatment for the importation of taxable services and digital services to ensure that the tax on services can be enforced smoothly (Malaysian Reserve, 2020). They include:

- Group relief facilities for business-to-business groups on the importation of qualifying taxable digital services from service providers that are businesses of the same group based abroad.

- Local service providers are also excluded from factoring in and paying digital service tax using the self-recipient form of accounting for the importation of taxable services in order to prevent double taxation.

- Local service providers in the business-to-consumer community could make refund claims from the Customs Department if they made any service tax payments to international service providers on the basis of the actual amount of service tax charged.

- Furthermore, the Customs Department issued a Guide to Foreign Service Providers (FSPs) containing frequently asked questions that can be accessed via the Malaysia Sales and Sales Tax Portal to assist FSPs in understanding and implementing digital service tax.

With the DST, Malaysia intended to update its tax laws and policies so as to ensure that its tax base adequately represents the size of transactions and income created by the digital economy. At the same time, it took care not to interfere with the development of the digital economy (World Bank, 2018).

Nevertheless, Malaysia currently has inadequate means of taxing cross-border transactions in the digital economy. In January 2018, Malaysia took a big step in addressing the issue of taxation of digital services by signing a multilateral convention to amend international tax laws. The World Bank (2018) noted that Malaysia has three options for taxing the digital economy:

i) Expanding the tax base to businesses based outside the country

ii) Levelling the playing field among domestic and foreign firms

iii) Supporting mainstream taxation

\section{Indonesia:}

\section{DST Implementation}

- Effective date: 1 August 2020 
- Rate: $10 \%$

- Threshold:

- If the transaction value exceeds $600 \mathrm{~m}$ Indonesian Rupiah (IDR) in a 12-month period - or if the monthly IDR $50 \mathrm{~m}$ threshold is surpassed - then non-resident businesses that cross the threshold may voluntarily register for VAT purposes in Indonesia (Taxamo, 2020c).

- As a secondary threshold level, the level of traffic is used in combination with the monetary threshold. The threshold is surpassed if the amount of traffic or access in Indonesia reaches 12,000 users per year or 1,000 users per month (Taxamo, 2020c).

\section{Description of the DST and Tax Categories}

The country's plan to enact VAT at a rate of $10 \%$ on digital services provided by non-residents became operational on 1 August 2020. Non-resident digital businesses with sales to Indonesian consumers are required to register, collect, and remit VAT on their sales in the country. The initial application date was 1 July 2020, but this was delayed by one month to 1 August (Taxamo, 2020b).

Indonesia's Directorate General of Taxes has appointed digital service providing companies to act as VAT collectors under its new VAT rules concerning the supply of digital services to consumers based in Indonesia (Taxamo, 2020c).

- Initially, on July 72020 , six digital service provider companies were listed for the tax: Amazon Web Services Inc.; Google Asia Pacific Pte. Ltd.; Google Ireland Ltd.; Google LLC.; Netflix International B.V., and Spotify AB.

- A second wave of ten companies were added a month later, on 7 August 2020 including Facebook; Walt Disney Company (SE Asia); additional Amazon subsidiaries; Apple Distribution International Ltd, and TikTok.

- The third wave of additional companies, identified on 8 September 2020, include: Linkedln Singapore Ltd; McAfee Ireland Ltd; Skype, Twitter, and Zoom.

- The fourth such list was published on 9 October 2020. The eight companies selected were: Alibaba Cloud (Singapore) Pte Ltd; GitHub, Inc.; Microsoft Corporation; Microsoft Regional Sales Pte. Ltd.; UCWeb Singapore Pte. Ltd.; To The New Pte. Ltd.; Coda Payments Pte. Ltd., and Nexmo Inc.

- A fifth round, included an additional 10 major companies, namely: Cleverbridge AG Corporation; Hewlett-Packard Enterprise USA; Softlayer Dutch Holdings BV (IBM); PT Bukalapak.com; PT Ecart Webportal Indonesia (Lazada); PT Fashion Eservices Indonesia (Zalora); PT Tokopedia; PT Global Digital Niaga (Blibli.com); Valve Corporation (Steam), and beIN Sports Asia Pte Limited.

Indonesia's Directorate General of Taxes explained that for marketplaces appointed tax collectors, VAT collection is only carried out on the sales of digital goods and services by foreign sellers which sell via the marketplace (Taxamo, 2020c). 


\section{Economic Impact of the DST (Intended/Realised)}

Indonesian tax authorities disclosed that the introduction of these new VAT rules were able to bring in USD 20.9 million from nominated non-resident businesses in the first three months (August to October) of their implementation (Taxamo, 2020c; Jakarta Post, 2020). ${ }^{6}$

\section{Vietnam:}

\section{DST Implementation}

- Effective date: initially planned for July 2020 (postponed to mid-2021) ${ }^{7}$

- Rate: $10 \%$

- Threshold: N/A

\section{Description of the DST and Tax Categories}

Vietnamese tax authorities issued a new tax law charting the duty of overseas companies without an official presence in the country in October 2020. These companies have to pay 10 percent VAT from July 2020. Major foreign digital businesses targeted by the tax include Netflix, Alphabet (the parent company of Google), Facebook, Microsoft, and Alibaba Cloud. Other companies also include GitHub, UCWeb Singapore, Coda Payments, and Nexmo Inc (Taxamo, 2020d; KPMG, 2020).

The government is currently developing a new centralized IT platform to specifically deal with the collection of the new withholding tax regime on e-commerce/digital services (KPMG, 2020). That is, in a cross-border trade involving digital services, a $10 \%$ tax is withheld by the Vietnamese party to the contract. This is known as a 'Foreign Contractor Tax (FCT)', of which half is VAT $(5 \%)$ and half is an income tax (5\%) (Taxamo, 2020d). In the meantime, the Vietnamese Ministry of Information and Communications and the Ministry of Finance are in conjunction with adapting existing tax regulations towards the specific responsibility of cross-border digital service providers (VIR, 2020).

A new Vietnam law extended VAT to digital/online sales from foreign sellers. This was initially expected to come into effect in December 2020 (however, delays are possible). ${ }^{8}$ The planned new digital tax collection mechanisms appear to be a mix of voluntary registration by foreign online sellers and VAT collection from financial intermediaries. The FCT, in this case, would be

\footnotetext{
${ }^{6}$ https://www.thejakartapost.com/news/2020/11/24/indonesia-collects-20-9m-in-digital-tax-as-of-october.html

${ }^{7}$ A draft tax law in Vietnam that would have a significant effect on cross-border eCommerce (previously planned for 1 July 2020) is unlikely to be implemented any time soon. Back in June 2019, Vietnam adopted the 'Law on Tax Administration'. Contained within this regulatory update were plans for foreign eCommerce companies to register for Vietnam VAT purposes (Taxamo, 2020d). The initial timeline (effective date) for the tax was moved from July 2020 to mid-2021, partly due to interruptions caused by COVID-19.

8 This follows the publication of an extensive legislative Decree 126/2020/ND-CP (Taxamo, 2020d).
} 
replaced by VAT at a rate of $10 \%$ rather than the aforementioned split - i.e. $5 \%$ VAT and $5 \%$ income tax (Taxamo, 2020d).

The new tax decree allows for a framework for international digital service sellers to register with a local Vietnamese tax code and to voluntarily comply with domestic VAT obligations which they have not previously been able to comply with without the need for a physical presence in Vietnam. Voluntary enforcement and remittance is the ultimate goal here. Financial intermediaries will, conversely, be forced to withhold the VAT due on these digital service sales where foreign sellers do not register voluntarily (Taxamo, 2020d).

\section{Economic Impact of the DST (Intended/Realised)}

Vietnam's capacity to levy taxes on international digital platforms may soon get better due to OECD's new multilateral tax rules (see Section 2.2 and Annex), focusing on expanding the country's taxing rights under international laws (VIR, 2020).

It is estimated that "overseas over-the-top media service" (OTT) sites (such as Netflix, Amazon Prime, etc.) are serving about one million subscribers in Vietnam with total revenue of nearly VND1 trillion annually (about USD 43.5 million). Their operations in Vietnam have constantly improved over the years - for instance, Netflix in the first quarter of 2020 saw a 60 percent rise in subscribers year-on-year. Other international platforms such as Airbnb, Facebook, and Google are also being assessed (for digital services tax) by Vietnamese tax authorities. Facebook and Google occupy nearly 70 percent of Vietnamese advertising market share, with annual revenues of hundreds of millions of US dollars (VIR, 2020).

\subsubsection{Africa}

\section{Kenya:}

\section{DST Implementation}

- Effective date: 1 January 2021

- Rate: $1.5 \%$

- Threshold: None

\section{Description of the DST and Tax Categories}

Kenya is moving ahead with a unilateral tax on digital services - i.e. prior to the OECD and G20 consensus on a universally accepted framework for the taxation of the digital economy. Kenya first considered the taxation of income accrued in the digital sector in 2019, when the Finance Act 2019 ('FA 2019') amended the Income Tax Act to clearly allow for income received in the digital marketplace to be taxed on income. FA 2019 introduced the concept of a "digital marketplace" to mean a platform that allows direct interaction between buyers and sellers of goods and services via digital means. Afterwards, Kenya also enacted Finance Act 2020 ("FA 2020 ") which required DST to be payable on the gross value of a service contract. Although there was no definition of the gross value of the transaction. Another significant proposal on the gross value of the deal is that it would not contain VAT (Hira et al., 2020). 
The DST involves a $1.5 \%$ tax on the gross transaction value of the digital service. The DST is an advance tax for residents and non-residents with a permanent establishment (PE) in Kenya and a final tax for non-residents with no PE in Kenya (Hira et al., 2020). ${ }^{9}$

The DST regulation would apply to a wide variety of digital services that individuals and companies use often. It proposes to extend to digital content streaming and downloadable services; the transmission of data collected from users created from digital marketplace activities, but monetized; the provision of digital marketplaces, websites or other online applications linking buyers and sellers; subscription-based media, including news, magazines and journals; electronic data management, including website hosting, online data storage, file sharing and cloud storage services; the provision of search engine and automated support desk services, including the provision of personalised search engine services; tickets for live events, theatres, restaurants, etc. purchased over the Internet online distance learning through pre-recorded medium or eLearning, including online learning (Hira et al., 2020; Mekgoe and Hassam, 2020).

The DST regulations are proposed to extend to any other service offered or distributed via an online digital or electronic network but excluding those services that are subject to withholding tax under the Income Tax Act. This ensures that payments made for sales promotion, advertisement, and advertising services subject to withholding tax under the Income Tax Act would not be subject to the DST (Hira et al., 2020).

Interesting exclusions from chargeable services include services offered by a licenced financial service provider offering on-line services that allow payment, lending or trading of financial instruments, financial securities, or foreign exchange services (Hira et al., 2020).

\section{Economic Impact of the DST (Intended/Realised)}

A report of the Finance Committee of the National Assembly (on "FA 2020") claimed that the Exchequer is preparing to collect KES 2 billion from the DST (Hira et al., 2020).

The net effect of the proposed DST is that customers may end up paying higher prices for digital services or that companies in the digital sector may be able to absorb costs at the detriment of their bottom line. Tax authorities are also expecting compliance problems due, among others, to the lack of visibility by the Kenyan Revenue Authority (KRA) of digital services-related digital transactions and the inadequacy of punitive steps for non-residents without an PE in Kenya. ${ }^{10}$ However, any additional revenue raised by the taxpayer (and expansion of KRA's tax base) is seen as positive - since it may help Kenya to deal with the ongoing fiscal crisis (partly due to COVID-19). In addition, the DST achieves the constitutional concept of tax equality/fairness by

\footnotetext{
${ }^{9}$ Users shall be deemed to be located in Kenya if they (a have access to a digital interface from a terminal device) located in Kenya; (b) have a credit/debit facility service provided by a Kenyan company; (c) have access to an IP address registered in Kenya or to an international cell phone country code assigned to Kenya; or (d) have a business, residence or billing address in Kenya (Hira et al., 2020).

10 The arduous roll out of statutory measures to expedite the taxation of income over the last few years proves the challenges that await the actual implementation of the DST measures from 1 January 2021 (Hira et al., 2020).
} 
subjecting foreign players in the digital sector who have long benefited from the inadequacy of the conventional tax system by paying zero or nominal income tax in Kenya (Hira et al., 2020; Gakweli, 2020).

\section{Nigeria}

\section{DST Implementation}

- Effective date: To be confirmed

- Rate: $30 \%$ (Included in gross income for CIT purposes)

- Threshold: NGN 25million (circa USD 65,000)

\section{Description of the DST and Tax Categories}

Nigeria plans to tax the income generated by foreign (digital services provider) companies in respect to their activities - including electronic commerce, high-frequency trading, electronic data storage, online adverts, participative network platform, online payments and so on, to the extent that the foreign business has a "significant economic presence" in Nigeria and that profit can be linked to such activity (Mekgoe and Hassam, 2020).

Tax authorities published the Companies Income Tax ("Significant Economic Presence" (SEP)) Order 2020. The Order provides that a foreign company shall have an SEP in Nigeria in any accounting year where it derives 25 million Nigerian nairas $(\$ 65,00)$ annual gross turnover or its corresponding amount in other currencies from digital services (Obayomi and Adegite, 2020; Obayomi and Adegite, 2020). ${ }^{11}$

The Order exempts international corporation from SEP if their operation falls under a "multilateral agreement" and a consensus arrangement to resolve the tax issues resulting from the digitization of the economy. This appears to be an exception tailored to make room for any agreement that can be achieved by the OECD in the ongoing negotiations on the taxation of the digital economy. This would ensure a smooth transition and eventually remove the administrative process of issuing another Order to enforce any agreement reached by the OECD (Obayomi and Adegite, 2020).

\footnotetext{
${ }^{11}$ These digital services/activities may include provision of intermediation services through a digital platform, website or other online applications that link suppliers and customers in Nigeria; streaming or downloading services of digital contents; and transmission of data collected about Nigerian users which has been generated from such users' activities on a digital interface, including websites or mobile applications (Obayomi and Adegite, 2020; Obayomi and Adegite, 2020).
} 


\section{Economic Impact of the DST (Intended/Realised)}

The "significant economic presence" (DST) order draws heavily on proposals made in the OECD/G20 BEPS project report on "addressing the tax challenges of the digital economy". ${ }^{2}$ However, even if the order seems to resolve the challenge of taxable nexus, it brings up other problems, including cost allocation, compliance and enforcement, the adequacy of the tax threshold, and impact of the DST order on tax treaties (Nwodo and Omoniyi, 2020).

Further, the value chain for the provision of digital services can be very complex in Nigeria (and other developing countries). One example from Nigeria was the dispute between Vodacom Business Nigeria Limited versus Nigeria's Federal Inland Revenue Service in 2018, where the subject of litigation was whether the bandwidth services provided via a satellite (in space) which was controlled by a non-resident company were liable to value-added tax in Nigeria.

Unfortunately, the "significant economic presence" Order gives no clarification on the ownership or control of the electronic or wireless apparatus, such as satellite or other connected servers, receivers, or transponders, used in the provision of digital services. This is a considerable omission given the complexity of the value chain of digital services involving the use of satellites and associated equipment (Obayomi and Adegite, 2020).

\section{Zimbabwe}

\section{DST Implementation}

- Effective date: 1 January 2019

- Rate: $5 \%$

- Threshold: Revenue over USD 500, 000 in any year of assessment

\section{Description of the DST and Tax Categories}

Zimbabwe charges taxes on gross income from satellite broadcasting services (effective since January 2019) in respect of the provision or delivery of television or radio programmes, and on ecommerce, operators providing or delivering goods or services to persons resident in Zimbabwe (Mekgoe and Hassam, 2020). ${ }^{13}$

Zimbabwe also updated its VAT rules (with effect from 1 January 2020) to tax the provision of digital services offered by non-residents to customers based in Zimbabwe. The rules require the non-resident enterprises concerned to register with the Zimbabwean tax authority to collect and remit VAT on such sales. Supplies impacted include online sales of e-books, games, apps, videos, etc. In September 2020, Facebook announced that Zimbabwe's advertisers would be

\footnotetext{
12 https://doi.org/10.1787/9789264241046-en

${ }^{13}$ A Zimbabwean High Court nullified a previous 2\% digital transactions tax that was imposed in 2018. Zimbabwe's high court argued that the tax was imposed "without a legal instrument", and also "overrode parliament". However, the government argued that this ruling had no actual effect on the collection of the tax because a legislation has (consequently) been passed to give the tax "legality". That is, the special instrument was superseded by the Finance Act, which was passed by parliament to give the bill legal effect (Marawanyika and Sguazzin, 2019).
} 
paying VAT on the sale of ads based on the new regulations on the supply of digital content in Zimbabwe (Taxamo, 2020e).

\section{Economic Impact of the DST (Intended/Realised)}

Zimbabwe's treasury raised, on average, $\$ 100$ million (about $\$ 7.24$ million a month from the tax levied in 2018 (the initial DST tax), according to the Treasury. The tax is particularly effective in Zimbabwe, as a persistent lack of physical cash means that almost all trade takes place electronically, much of it via mobile phone (Marawanyika and Sguazzin, 2019).

\subsection{Other Examples of DST}

\subsubsection{African Countries with DST intentions (announced)}

ATAF released a policy document titled "Domestic Resource Mobilisation - Digital Services Taxation in Africa" in June 2020. ${ }^{14}$ In this document, ATAF announced that it is in the process of developing a "suggested approach to drafting digital services tax legislation". The suggested approach aims to provide African countries with a structure and framework for introducing a digital sales tax (ATAF, 2020; Mekgoe and Hassam, 2020).

The ATAF (2020) policy document does not provide details regarding the suggested approach. Nevertheless, it states that proposed DST should not take the form of an income tax but instead suggests some form of a final withholding tax that will be levied as a supplement to local income tax (Mekgoe and Hassam, 2020).

Africa's other major economies, particularly Egypt and South Africa, have also recently announced their plans to introduce DST.

\section{Egypt:}

Following a meeting with a major multinational digital enterprise in August 2019, the Egyptian finance minister suggested that Egypt is considering the introduction of a digital tax on social media and digital advertising platforms. Nonetheless, it remains unclear when the relevant tax laws will be enacted or the manner in which those laws will be implemented (Mekgoe and Hassam, 2020).

It has been reported that businesses using advertisements/ads on social media sites, including Facebook, Twitter, Instagram, and Google search ads, would have to pay 15-20 percent stamp tax. The tax is expected to be paid on the overall cost of the ads. Brands and companies in Egypt pay stamp tax in a similar range for their print ad purchases per company. What is not clear, however, is that how the government would be able to gather information on who spends how much money on advertising on these social media sites such as Facebook, Twitter or Instagram - since these sites have no legal/physical presence in Egypt. It was noted that the tax treatment

\footnotetext{
${ }^{14}$ https://events.ataftax.org/index.php?page=documents\&func=view\&document_id=61
} 
of each type of operation would include amendments to the VAT Act, the Stamp Tax Act, the Income Tax Act, and the E-Commerce Act (Menabytes, 2019).

It was reported that other companies operating (digital services) online would pay the standard $22.5 \%$ tax on profits and the individual traders "will be taxed at their marginal rate." E-commerce platforms in the country had also started charging 14\% VAT on their products after being asked by the government to do so and remit taxes to them. Uber, the ride-hailing company, had also reached an agreement with the Egyptian Tax Authority to pay VAT in the country in February 2019. Careem (a Dubai based vehicle for hire company - which is currently a subsidiary of the American company Uber) had been paying VAT since March 2018 (Menabytes, 2019).

\section{South Africa:}

South Africa was one of the first African countries to bring digital services within its indirect tax (VAT) network. Nevertheless, little attention has been paid to developments on the direct tax front. Given that the collection of revenues is expected to suffer as a result of the restrictive COVID-19 measures put in place, it would not be unexpected for the South African tax authorities explore the possibility of introducing a direct digital tax (DTS, 2016; Mekgoe and Hassam, 2020).

While summarising its findings on the implementation of BEPS in South Africa in 2016, the Davis Tax Committee (DTC) recognised the balance that needs to be struck between the implementation of a digital tax while at the same time taking into account the unique economic circumstances and economic policies aimed at encouraging foreign direct investment to foster economic growth. ${ }^{15}$ Furthermore, DTC (2016) suggested that South Africa should await the outcome of the OECD BEPS project on the digital economy in order to remain competitive internationally and escape double taxation and double non-taxation of profits from the supply of digital products or services.

Considering that South African corporate tax revenue as a share of revenue has declined in recent years and that more companies have become more digitalised, it is important to consider tax initiatives that will enable revenue from digital economic activities to be increased. By applying this strategy, South Africa will pursue recent international trends, which would not only provide the additional revenue required, but would also ensure that all business activities contribute their fair share to the tax burden (Jantjies, 2020).

\footnotetext{
${ }^{15}$ https://www.taxcom.org.za/docs/New_Folder3/2\%20BEPS\%20Final\%20Report\%20\%20Introductory\%20Report.pdf
} 


\subsubsection{South American Countries with DST (Announced and/or Implemented)}

\section{Argentina:}

At a sub-national level, the City of Buenos Aires sought a withholding tax on digital services in 2014. Nevertheless, the tax was postponed for the next year in order to enable withholding agents - credit card companies - time to better adjust their tax collection systems. At the federal level, the tax on digital services is on the tax reform agenda aimed at the end of 2017, but Argentina is currently taxing only digital goods (i.e. goods sold to Argentina by online sales) and not services. Some provinces, such as Córdoba, have implemented a turnover withholding tax for some services (including digital services) rendered by foreign parties, but the regulations are not yet in effect (Deloitte, 2017).

Argentina has had a VAT on digital services in place since June 27,2018 . The VAT was expanded to between 29 and 30 percent in 2020 following the enactment of the "País tax", which was meant to realize "an inclusive and supportive Argentina". The liability for the collection and remittance of the VAT on digital services falls on the payment provider for Argentine consumer's and not on the non-resident company which is offering the products or services. This is an interesting decision (perhaps from tax compliance point of view) but goes against OECD recommendations. OECD guidelines, on the other hand, place the liability for collection and remittance of VAT/GST on the non-resident supplier (Taxlinked, 2020; Taxamo, 2020f).

Another noteworthy element of the new Argentine rules is that not all digital services fall under the digital tax rule. Domestic consumers and payment providers can view this list to understand the digital services for which VAT should be applied (Taxamo, 2020f).

\section{Chile:}

Chile uses a territory-based VAT system, and digital services provided from outside of Chile normally do not fall under the scope of Chilean VAT. Chile also operates a direct tax withholding mechanism which applies to most payments made to non-residents. Thus, the provision of digital services by non-residents to Chilean customers will be subject to such withholding, which in theory guarantees that such digital services are taxed in Chile (Deloitte, 2017).

Starting on June 1, 2020, "over-the-top media service" businesses and other firms involved in the provision of digital services such as Amazon, Netflix, AirBnB and Spotify have to pay a 19 percent VAT on their products and services. This new VAT applies to the intermediation of services provided in Chile; the supply or delivery of digital entertainment content; the provision of software, storage, platforms or IT infrastructure; and advertising, regardless of the medium through which it is provided (Taxlinked, 2020).

Through this levy, tax authorities expect to collect close to USD 2.2 billion in revenue. In order to cover for this unexpected expense, many digital services providers have already passed on this charge to consumers - for instance, pushing up subscription prices for Netflix by close to 20 percent (Taxlinked, 2020). 


\section{Mexico:}

Mexico began charging VAT on the sale of digital services on 1 June 2020. Under this initiative, the government would tax online purchases made by customers based in Mexico, regardless of whether the seller has a physical presence in Mexico or not. Targeted services include downloading and/or viewing a wide range of digital contents - including movies, music, text, documents, gaming (including gambling), etc. (Taxlinked, 2020; Mialik, 2020).

\section{Good DST Design}

A good DST system should ensure tax neutrality and efficiency (Bunn et al., 2020):

- Tax Neutrality: Taxes should not interfere with the decisions of taxpayers. That is, digital taxes should be applied in a way that does not force consumers to choose one mode of trade (e.g. cross-border electronic trading) over another (e.g. traditional local trade). Developing countries which apply the same VAT rate for cross-border and domestic transactions, as well as the same VAT rate for digital and non-digital goods, offer a neutral system of taxation. Also, based on the same principle of neutrality, international and domestic sellers should be subject to identical VAT exemption/registration thresholds. A neutral extension of VAT to digital content reduces the untaxed distortion of digital use when comparable locally purchased products or services face taxation (Bunn et al., 2020).

- Tax Efficiency: Implementing tax systems that are reliable and easy to deal with from an administrative and enforcement point of view is crucial. A tax structure should be effective in the sense that the taxpayers' enforcement costs and the tax authorities' administrative costs should be reduced to the full extent possible. Nonetheless, the amount of information that companies have to gather about transactions and their customers in certain developing countries is burdensome and, in some cases, could breach trade secret privacy laws. Policymakers need to balance information requirements' enforcement costs against the need to check compliance with VAT rules (Bunn et al., 2020; Bulusu and Ali, 2020; OECD, 1998).

Thus, taxation should seek to be neutral (i.e. low interference in business decisions), effective (i.e. low compliance issues), and equitable across all sectors of the economy. A distortion arises when a rise in the price of a product resulting from taxation causes different changes in supply and demand from that which would occur in the absence of taxes. Taxes can create distortions if they influence the choices made by market agents which could be the following in the digital space (Katz, 2015).

- Consumers of digital services, especially those that are price sensitive, face an affordability hurdle in the adoption of technology if taxes raise the total cost of ownership.

- Various types of tax regimes within the digital eco-system could generate asymmetries across industrial sectors. 
- Digital service providers (e.g. telecommunications/ICT service providers) may reduce their rate of investment in infrastructure if taxes reduce the total available capital to be spent.

Katz (2015) also identifies the distortive effect of taxes in the digital eco-system on three levels:

- First, there is a potential disparity in tax burdens imposed on telecommunication operators when compared to other operators of the digital eco-system (e.g. digital advertisers and social networks).

- This is partly due to compliance challenges in taxing the latter - which often involve overseas-based technology companies. This may, hopefully, change once the multilateral OECD proposal is adopted.

- Second, there is a taxation asymmetry between global players in the digital sector.

- Third, there is also "in-country" taxation asymmetry between the telecommunication sector and other providers of (i.e. non-digital) goods and services.

Developing country governments should, therefore, analyse these asymmetries in order to identify whether digital taxes are a source of distortions. Moreover, given the considerable indirect impact of digital platforms (such as on business creation and transactional efficiency), governments should carefully examine the issue of taxation of digital players. In developing fiscal policies, governments need to consider trade-offs between the generation of revenue and the potential negative impact on the development of the digital sector. Research on the area (by donors or academics) should also strive to identify country-specific policy trade-offs between revenue generation and the potential negative effect on the development of the digital sector (Katz, 2015).

\section{References}

ATAF (2020). Domestic Resource Mobilisation - Digital Services Taxation in Africa. The African Tax Administration Forum.

https://events.ataftax.org/index.php?page=documents\&func=view\&document_id=61

Asen, E. (2020). What European OECD Countries Are Doing about Digital Services Taxes. Tax Foundation. (Accessed 22 Nov. 2020). https://taxfoundation.org/digital-tax-europe-2020/

Azzopardi, T. (2020). Chile's New Digital Services Tax to Send Netflix Prices Up. Bloomberg Tax. (Accessed 25 Nov. 2020). https://news.bloombergtax.com/\%20daily-tax-reportinternational/chiles-new-digital-services-tax-to-send-netflix-prices-up

Bulusu, S. and Ali, H. (2020). Global Value-Added Tax Crackdown Costing Companies Millions. Bloomberg Tax. (Accessed 22 Nov. 2020). https://news.bloombergtax.com/daily-laborreport/global-value-added-tax-crackdown-costing-companies-millions?context=article-related

Bunn, D. (2020). The U.S. Trade Representative Expands Its Digital Services Tax Investigations. Tax Foundation. (Accessed 22 Nov. 2020). https://taxfoundation.org/us-trade-representative-ustrdigital-services-tax-investigations/ 
Bunn, D., Assen, E., \& Enache, C. (2020). Digital taxation around the world. Tax Foundation. Washingtion. https://files.taxfoundation.org/20200610094652/Digital-Taxation-Around-theWorld1.pdf

Deloitte (2017). Indirect tax challenges of the digital economy in Latin America. Deloitte. (Accessed 25 Nov. 2020).

https://www2.deloitte.com/content/dam/Deloitte/global/Documents/Tax/gx-indirect-taxchallenges-digital\%20economy-latin-america.pdf

Deloitte (2020). Statement on two-pillar approach to tackling tax challenges of digitalization issued. Deloitte. (Accessed 22 Nov. 2020).

https://www.taxathand.com/article/12872/Australia/2020/Statement-on-two-pillar-approach-totackling-tax-challenges-of-digitalization-issued

DTS (2016). Davis Tax Committee: Second Interim Report on Base Erosion and Profit Shifting (BEPS) In South Africa: Introduction. Davis Tax Committee.

https://www.taxcom.org.za/docs/New_Folder3/2\%20BEPS\%20Final\%20Report\%20-

\%20Introductory\%20Report.pdf

Eurostat (2020). Main National Accounts Tax Aggregates. Eurostat .

https://appsso.eurostat.ec.europa.eu/nui/show.do?dataset=gov_10a_taxag\&lang=en

Gakweli, M. (2020). KRA Invites Comments On 1.5\% Digital Tax. The Kenyan Wallstreet. (Accessed 23 Nov. 2020). https://kenyanwallstreet.com/kra-invites-public-commentary-ondigital-tax/

Hira, N., Magonga, D. and Mathini, A. (2020). Kenya Sets The Stage For Implementation Of The Digital Services Tax. Bowmans. (Accessed 23 Nov. 2020). https://www.mondaq.com/withholdingtax/990472/kenya-sets-the-stage-for-implementation-of-the-digital-services-tax

Jantjies, D. (2020). Tax Brief: Digital Economy and Taxation Policy Considerations. Parliament of the Republic of South Africa, Parliamentary Budget Office. https://businesstech.co.za/news/wpcontent/uploads/2020/06/Parliamentary-Budget-Office.pdf

Katz, R. (2015). The impact of taxation on the digital economy. In 15th Global Symposium for Regulators (pp. 1-61). GSR15 discussion papers. International Telecommunication Union (ITU). https://www.itu.int/en/ITU-

D/Conferences/GSR/Documents/GSR2015/Discussion_papers_and_Presentations/GSR16_Disc ussion-Paper_Taxation_Latest_web.pdf

Kofler, G. and Sinnig, J. (2019). Equalization Taxes and the EU's 'Digital Services Tax'. INTERTAX, Volume 47, Issue 2. pp. 176-200, https://kluwerlawonline.com/journalarticle/Intertax/47.2/TAXI2019017

KPMG (2020). Vietnam: Taxation of e-commerce, withholding rules effective in 2021. KPMG. (Accessed 23 Nov. 2020). https://home.kpmg/us/en/home/insights/2020/06/tnf-vietnam-taxatione-commerce-withholding-rules.html

Malaysian Reserve (2020). Govt to collect RM300m of digital tax this year. The Malaysian Reserve. (Accessed 26 Nov. 2020). https://themalaysianreserve.com/2020/09/10/govt-to-collectrm300m-of-digital-tax-this-year/ 
Marawanyika, G. and Sguazzin, A. (2019). Zimbabwe's High Court Annuls 2\% Digital Transactions Tax. Bloomberg. (Accessed 25 Nov. 2020).

https://www.bloomberg.com/news/articles/2019-09-18/zimbabwean-court-annuls-2-digitaltransactions-tax-herald-says

Mekgoe, N. and Hassam, M. (2020). Digital services tax in Africa - The journey so far: Implementation of digital taxes across Africa. Deloitte. (Accessed 22 Nov. 2020) https://www2.deloitte.com/za/en/pages/tax/articles/digital-services-tax-in-africa-the-journey-sofar.html

Menabytes (2019). Egypt moving forward with plans of imposing tax on social media and search ads: report. Menabytes. (Accessed 23 Nov. 2020). https://www.menabytes.com/egypt-socialmedia-search-ads-tax/

Mialik, H. (2020). Mexico's New Value-Added Tax On Digital Services. Mondaq. (Accessed 23 Nov. 2020). https://www.mondaq.com/mexico/sales-taxes-vat-gst/899330/mexico39s-new-valueadded-tax-on-digital-services

Nwodo, G. and Omoniyi, O. (2020). Nigeria clarifies new tax on nonresident digital businesses. MNE Tax. (Accessed 23 Nov. 2020). https://mnetax.com/nigeria-clarifies-new-tax-onnonresident-digital-businesses-39269

Obayomi, W. and Adegite, V. (2020). Taxation of Digital Economy in Nigeria-Significant Economic Presence. Bloomberg Tax. (Accessed 23 Nov. 2020).

https://news.bloombergtax.com/daily-tax-report-international/insight-taxation-of-digital-economyin-nigeria-significant-economic-presence

OECD (2015). Addressing the Tax Challenges of the Digital Economy, Action 1 - 2015 Final Report. OECD. https://doi.org/10.1787/23132612

OECD (2018). Tax Challenges Arising from Digitalisation - Interim Report 2018: Inclusive Framework on BEPS. OECD/G20 Base Erosion and Profit Shifting Project, OECD Publishing, Paris, https://doi.org/10.1787/9789264293083-en

OECD (2020a). Statement by the OECD/G20 Inclusive Framework on BEPS on the Two-Pillar Approach to Address the Tax Challenges Arising from the Digitalisation of the Economy. OECD/G20 Base Erosion and Profit Shifting Project. OECD.

http://www.oecd.org/tax/beps/statement-by-the-oecd-g20-inclusive-framework-on-beps-january2020.pdf

OECD (2020b). OECD Secretary-General Tax Report to G20 Finance Ministers and Central Bank Governors. OECD. http://www.oecd.org/ctp/oecdsecretary-general-tax-report-g20-financeministers-riyadh-saudi-arabia-february-2020.pdf

OECD (2020c). Global revenue statistics database. Organisation for Economic Co-operation and Development. https://www.oecd.org/tax/tax-policy/global-revenue-statistics-database.htm

OECD (1998). Electronic Commerce: Taxation Framework Conditions. Organisation for Economic Co-operation and Development. https://www.oecd.org/ctp/consumption/1923256.pdf

Taxamo (2020a). Malaysia digital service tax set for January 2020 introduction. Taxamo. (Accessed 24 Nov. 2020). https://blog.taxamo.com/insights/malaysia-digital-tax-annoucement 
Taxamo (2020b). Tax developments affecting digital sales in South-East Asia. Taxamo. (Accessed 24 Nov. 2020). https://blog.taxamo.com/insights/digital-tax-news-south-east-asia

Taxamo (2020c). Indonesia tax on digital services supplied by non-residents. Taxamo. (Accessed 24 Nov. 2020). https://blog.taxamo.com/insights/indonesia-tax-digital-services

Taxamo (2020d). Vietnam VAT obligations on sales by foreign online sellers may come into force on December 5. Taxamo. (Accessed 24 Nov. 2020). https://blog.taxamo.com/insights/vietnamtax-digital-services

Taxamo (2020e). Africa: taxing digital services supplied by foreign companies. Taxamo. (Accessed 24 Nov. 2020). https://blog.taxamo.com/insights/africa-digital-services-tax

Taxamo (2020f). Argentina tax to impact sales of digital services by non-residents. Taxamo. (Accessed 24 Nov. 2020). https://blog.taxamo.com/insights/argentina-digital-services-tax

Taxlinked (2020). An Alternative Digital Services Tax: The Latin American Experience. Tax Linked. (Accessed 24 Nov. 2020). https://taxlinked.net/blog/november-2020/alternative-digitalservices-tax-latin-american-experience

VIR (2020). Tax duties closing in for digital services. Vietnam Investment Review. (Accessed 27 Nov. 2020). https://www.vir.com.vn/tax-duties-closing-in-for-digital-services-80777.html

World Bank (2018). Malaysia's Digital Economy: A New Driver of Development. World Bank. https://openknowledge.worldbank.org/bitstream/handle/10986/30383/129777.pdf

\section{Annex: OECD's Two-Pillar DST Approach}

\section{Pillar One - Nexus and profit allocation}

Three possible types of taxable profit may be allocated to a market country (Deloitte, 2020; OECD, 2020a):

I. "Amount A": New taxing right to provide a share of residual profit apportioned to market countries using a formulaic approach applied at a group (or business line) level, regardless of local physical presence.

Two broad groups of business have been recognized as having the ability to take part in a "sustained and significant manner" in the economic life of a market country, with or without local physical operations, such that they are in scope for the new taxing right:

- Automated digital services offered on a standardized basis to a large user base across several tax jurisdictions: These include: online search engines; social media platforms; online intermediation platforms (including online marketplaces used by businesses or consumers); digital content streaming; online gaming; cloud computing services, and online advertising services. 
- Professional services needing considerable human input in spite of digital delivery, such as: legal; accounting; architectural; engineering, and consulting services, are not in scope.

- Consumer-facing businesses that collect revenue from the sale of goods and services of a type commonly sold to consumers:

- Consumer products sold indirectly via third-party resellers and by intermediaries that undertake routine tasks (e.g., minor assembly or packaging) are in scope.

- Those businesses that generate revenue from licensing rights from trademarked consumer products and those that generate revenue through licensing a consumer brand (and commercial know-how) such as under a franchise model are in scope.

- The sale of intermediate products/components that are integrated into a finished consumer product that is sold to consumers will be out of scope, with a potential exception if the item is branded and commonly purchased by consumers for personal use.

- Some illustrations of in-scope consumer-facing businesses include: personal computing products (e.g., software, home appliances, mobile phones); clothes, toiletries, cosmetics, and luxury goods; branded foods and refreshments; franchise models, such as licensing arrangements involving the restaurant and hotel sector, and automobiles.

- Extractive industries and other producers/sellers of raw materials and commodities are excluded, even though those materials/commodities are integrated into consumer products further down the supply chain.

- It is proposed that regulated consumer-facing business lines in the financial services sector, for example in retail banks and insurance, may be broadly excluded from scope.

- Airline and shipping companies will also not be in scope.

- Different economic activities may need to be subdivided to distinguish between in-scope and out-of-scope segments. Where a business sells to both businesses and consumers, the revenues are in scope if the product is of a kind that is usually sold to consumers.

II. “Amount B": Fixed return for defined "baseline" marketing and distribution functions.

- Amount B seeks to standardize the remuneration of "baseline marketing and distribution activities" to enhance simplification in the administration of transfer pricing and to improve certainty. A fixed return for in-scope activities based on the arm's length principle is proposed, and Amount $B$ rules would not be optional or a safe-harbour.

- An additional work will be required to explore how to take account of different functionality levels, and differentiation in treatment between industries and 
regions, when deciding on the fixed return. An important consideration will be the determination of an appropriate profit level indicator. The definitions of baseline activities are to be further assessed, but possibly include distribution arrangements with routine levels of functionality, no ownership of intangibles, and no-or-limited risks.

III. "Amount C": Additional return based on a transfer pricing analysis where marketing and distribution activities in a country extend beyond the baseline level, together with enhanced dispute resolution procedures.

The scope of the new taxing right in accordance with the provisions of Pillar One (Amount A) has been clarified, concentrating on:

i. Digital businesses including those which offer cloud computing services, and

ii. Consumer businesses including franchise models.

At this phase of the negotiations on the OECD DST proposal, there is still no indication of the amount of residual profit to be reallocated to the market or to the user countries. In addition to international air and shipping companies, extractive and other commodity enterprises and regulated financial services companies appear to be largely excluded. The statement also clarifies that Amount $\mathrm{B}$ (baseline return for marketing and distribution activities) and Amount $\mathrm{C}$ (full transfer pricing under the arm's length principle for additional marketing and distribution activities) under Pillar One will apply to all businesses - irrespective of whether they are eligible for a new taxing right under Amount A (Deloitte, 2020).

The declaration confirms that changes will be made, in particular with regard to the new taxing right under Amount $A$, through a new multilateral instrument, so that countries adopt new rules at the same time. However, this is expected to take a number of years to be implemented through different countries' domestic bureaucratic procedures. In terms of timeline, the best estimate would suggest that the changes will apply only from 2023 onwards (Deloitte, 2020).

\section{Pillar Two - Global anti-base erosion proposal}

OECD (2020) provides only a short update on Pillar Two by mentioning issues linked to "minimum level of tax" of a tax regime. OECD (2020) also mentions that policy differences remain amongst negotiating countries with regard to the scope and intentions of the global "antibase erosion" proposal (Deloitte, 2020; OECD, 2020a). ${ }^{16}$

\footnotetext{
${ }^{16}$ The statement is focused on the agreed outline of the architecture of Pillar One for new nexus (taxable presence) and profit allocation rules, based on the unified approach proposal put forward by the OECD Secretariat in October 2019. The statement includes only a brief update on Pillar Two in relation to the global minimum tax proposals (Deloitte, 2020).
} 


\section{Suggested citation}

Megersa, K. (2020). Digital Service Taxes and Their Application. K4D Helpdesk Report 914. Brighton, UK: Institute of Development Studies. DOI: 10.19088/K4D.2021.135

\section{About this report}

This report is based on six days of desk-based research. The K4D research helpdesk provides rapid syntheses of a selection of recent relevant literature and international expert thinking in response to specific questions relating to international development. For any enquiries, contact helpdesk@k4d.info.

K4D services are provided by a consortium of leading organisations working in international development, led by the Institute of Development Studies (IDS), with Education Development Trust, Itad, University of Leeds Nuffield Centre for International Health and Development, Liverpool School of Tropical Medicine (LSTM), University of Birmingham International Development Department (IDD) and the University of Manchester Humanitarian and Conflict Response Institute (HCRI).

This evidence summary was prepared for the UK Government's Foreign, Commonwealth and Development Office (FCDO) and its partners in support of pro-poor programmes. It is licensed for non-commercial purposes only. Except where otherwise stated, it is licensed for non-commercial purposes under the terms of the Open Government Licence v3.0. K4D cannot be held responsible for errors, omissions or any consequences arising from the use of information contained in this health evidence summary. Any views and opinions expressed do not necessarily reflect those of FCDO, K4D or any other contributing organisation.

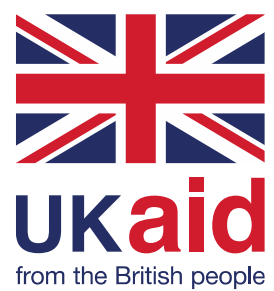

(C) Crown copyright 2020. 